\title{
Role of immunohistochemical markers in breast cancer and their correlation with grade of tumour, our experience
}

\begin{abstract}
Objectives: To study the immunohistochemical markers in invasive carcinoma of breast and to assess the relationship of hormonal receptors and Her2Neu oncoprotein with grade of tumour.

Materials and methods: This was a comparative cross sectional study conducted at Chughtais Lahore lab from Jan 2011-Oct 2011. Eighty two biopsy proven cases of breast carcinoma were reviewed. Immunohistochemistry was used to evaluate the expression of Estrogen receptors(ER) and progesterone receptors (PR) and Her2Neu oncoprotein. Grade of tumour was assessed by Scarf Bloom Richerdson Grading system.

Results: This study comprised 82 cases of invasive breast carcinoma. Out of these 82 cases, 2 were males and 80 were females. Majority of the cases were between $25-45$ years age group. Fifty seven cases $(69.5 \%)$ were of grade 2 and 25 cases were of grade $3(30.4 \%$ cases $)$. There was no grade 1 tumour in our study. Considering ER, PR and Her2Neu oncoprotein overexpression and grade of tumour, twenty five cases $(30.4 \%)$ were ER+ PR+ and Her2Neu negative and were all grade 2. Eleven cases $(13 \%)$ were $\mathrm{ER}+\mathrm{PR}$-and Her2Neu-and were grade 2 .Only one case $(1.2 \%)$ was ER$\mathrm{PR}+$ and $\mathrm{Her} 2 \mathrm{Neu}-$ and was again grade 2. Eight cases (9.7\%) were tripple negative with grade 3 morphology. Twenty seven cases were ER-PR-and Her2Neu positive $(32.9 \%)$. Eleven cases were ER-PR-and Her2Neu+ with grade 2 morphology and 16 cases were grade 3 . Ten cases $(12.1 \%)$ were tripple positive having 9 cases with grade 2 morphology and one case with grade 3 morpholgy.
\end{abstract}

Conclusion: Reactivity of steroid receptors decreases with increasing grade. Tripple negative tumours usually exhibit higher grade. Her2 Neu positivity is also associated with higher grade and poor survival rate.

Keywords: estrogen receptor, progesterone receptor, her2 neu, breast carcinoma
Volume 6 Issue 3 - 2018

\author{
Naila Atif, Muneeza Khalid, Omer Chughtai, \\ Saad Asif, Muhammad Rashid, Chughtai AS \\ Department of Pathologist, Azra Naheed Medical College, \\ Pakistan
}

Correspondence: Naila Atif, Department of pathologist, College of physicians and surgeons, Azra Naheed Medical College, Pakistan, Email nyleatif@gmail.com

Received: September 26, 2016 | Published: June 18, 2018

\section{Introduction}

Breast cancer is a major concern and one of the leading causes of cancer related death worldwide. Breast cancer like many other types of cancer is a complex heterogeneous disease controlled by a multitude of genetic and epigenetic alterations. ${ }^{1}$. In Pakistani females, breast carcinoma occurs at a younger age group. Infiltrating ductal carcinoma is the most common type of tumour. ${ }^{2}$ Male breast carcinoma is an uncommon disease. ${ }^{3}$ Less than $1 \%$ of all breast carcinomas occur in men. ${ }^{4,5}$ The pathology is similar to that of female breast cancer, and infiltrating ductal cancer is the most common tumor type. ${ }^{6}$ During the past two decades the mortality rate has declined significantly, primarily due to the early use of adjuvant chemotherapy as well as detection of earlier stage tumours due to increased screening. ${ }^{7,8}$ Prognosis and management of breast cancer is influenced by the classical variables such as histological type and grade, tumour size, lymph node status, and status of hormonal receptors, Estrogen receptors (ER) and progesterone receptors (PR) of the tumour and more recently Her2Neu oncoprotein status. ${ }^{8,9}$ ER expression is undoubtedly the most important biomarker in breast cancer, because it provides the index for sensitivity to endocrine treatment. ER positive tumours $(80 \%$ of breast cancer) use the steroid hormone estradiol as their main growth stimulus; ER is therefore direct target of endocrine therapies. PR expression is strongly dependent on the presence of ER. Tumours expressing PR but not ER are uncommon and represent $<1 \%$ of all breast cancer. ${ }^{10}$ The proto-oncogene $(\mathrm{C}-\mathrm{erb})$ has been localized to chromosome $17 \mathrm{q}$ and encodes a transmembrane tyrosine kinase growth factor receptor. The name for the Her2 $\mathrm{Neu}$ is derived from human epidermal growth factor receptor, as it features substantial homology with the epidermal growth factor receptor (EGFR). ${ }^{11,12}$ Amplification and/or overexpression of Her2/ Neu gene is routinely evaluated using immunohistochemistry and or/ fluorescence insitu hybridization (FISH) in all cases of invasive breast carcinoma. Her-2 Neu amplification occurs in about one quarter to one fifth of breast cancers. ${ }^{13}$ The purpose of this study was to analyze the immunohistochemical markers in invasive carcinoma of breast and to assess the relationship of hormonal receptor status and Her2 Neuoncoprotein over expression with tumour grade.

\section{Materials and methods}

This was a comparative cross sectional study conducted at Chughtais Lahore lab from Jan 2011-Oct 2011. Eighty two biopsy proven cases of breast carcinoma were reviewed. Immunohistochemistry was used to evaluate the expression of ER, PR and Her2Neu oncoprotein. The immunohistochemistry for ER, PR and Her2Neu was done on paraffin 
embedded blocks using primary monoclonal antibodies(Dako), for hormonal staining, Allred score was used which is semi-quantitative system that takes into consideration the proportion of positive cells (scored on a scale of 0-5) and staining intensity (scored on a scale of $0-3)$. The proportion and intensity were then summed to produce total scores of 0 or 2 through 8 . A score of $0-2$ was regarded as negative while 3-8 as positive. Inbuilt control i.e. normal breast tissue was evaluated for ER staining wherever included with tumour. ${ }^{14,15}$ The scoring system for Her2Neu was assessed as negative for scores of $0 \& 1+$ and positive for scores of $2+$ and $3+$. On the basis of ER, PR, and Her2 Neu expression, the patient divided into six groups: ER+ve/PR+ve, Her2 Neu -ve, ER+ive PR-ve and Her2 Neu -ve, ER-ve PR+ve and Her2 Neu-ve, ER+ve/PR+ve and Her2 Neu +ve and ER-ve PR-ve Her2Neu +ve and ER-ve, PR-ve Her2Neu -ve. Histological grade was calculated by modified Bloom-Richardson System (MBR) and divided into three grades (Grade 1-3). ${ }^{16,17}$

\section{Results}

This study comprised 82 cases of invasive breast carcinoma. Out of these 82 cases, two were males and 80 were females. Age range was between $25-85$ years. Regarding age group distribution, three age groups were made, First group (25-45 years), second group (46-65 years), third group (66-85 years). Forty one cases belonged to first group. Thirty one cases were of second group and only eight cases belonged to third group. However, the only two males included in this study belonged to second group.More than half of the cases are ER positive (Table 1). Majority of the cases belonged to grade 2 (Table 2). No grade 1 tumour was present in our study. Fifty seven cases $(69.5 \%)$ were of grade 2 and 25 cases were of grade $3(30.4 \%$ cases). Considering ER, PR and Her2Neu oncoprotein overexpression and grade of tumour, twenty five cases $(30.4 \%)$ were ER+ PR+ and Her2Neu negative and were all grade 2 . Eleven cases $(13 \%)$ were $\mathrm{ER}+\mathrm{PR}$-and $\mathrm{Her} 2 \mathrm{Neu}-$ and were grade 2 . Only one case $(1.2 \%)$ was ER-PR+ and Her2Neu-and was again grade 2. Eight cases (9.7\%) were tripple negative with grade 3 morphology. Twenty seven cases were ER-PR-and Her2Neu positive (32.9\%). Eleven cases (13.4\%) were ER-PR-and Her2Neu + with grade 2 morphology and 16 cases were grade 3 . Ten cases $(12.1 \%)$ were triple positive having 9 cases with grade 2 morphology and one case (1.2\%) with grade 3 morphology.

Table I Percentage of different Immunohiostochemical markers

\begin{tabular}{lll}
$\begin{array}{lll}\text { Immunohistochemical } \\
\text { marker }\end{array}$ & Number of patients & Percentage \\
\hline ER & 46 & $56 \%$ \\
PR & 36 & $43.90 \%$ \\
Her2Neu & 37 & $45.10 \%$ \\
\hline
\end{tabular}

Table 2 Comparative incidence of frequency of hormone receptor status

\begin{tabular}{|c|c|c|c|c|}
\hline Hormone receptor & Suvarchala et al. ${ }^{23}$ & Bhagat et al. ${ }^{30}$ & $\begin{array}{l}\text { Gethamala et } \\
\text { al. }{ }^{16}\end{array}$ & Present study 2016 \\
\hline $\mathrm{ER}+/ \mathrm{PR}+\mathrm{Her} 2 \mathrm{Neu}-\mathrm{ve}$ & 32.8 & 36.20 & 52 & 30 \\
\hline $\mathrm{ER}+/ \mathrm{PR}-\mathrm{Her} 2 \mathrm{Neu}-\mathrm{ve}$ & 14 & 12.06 & 2 & 13 \\
\hline ER-/PR+ Her 2 Neu -ve & 10.94 & 1.72 & 0 & 1.2 \\
\hline ER-/PR- Her $2 \mathrm{Neu}+$ ve & - & 27.85 & 25 & 32.9 \\
\hline Triple positive & - & - & I & 12 \\
\hline Triple negative & 42.19 & 25.86 & 20 & 9.7 \\
\hline
\end{tabular}

\section{Discussion}

Breast cancer is the most common cancer with increased mortality rate. In addition to pathological grade and stage, breast cancers are routinely assessed for hormone receptor status (ER) by immunohistochemistry and human epidermal growth factor receptor2 (HER2) expression by IHC or amplification by FISH in order to guide the choice of the appropriate adjuvant therapy. ${ }^{18}$ The aim of our study was to identify the common immunohistochemical markers in invasive breast carcinoma and to find out the relationship between hormonal receptor status and Her2Neu overexpression with the grade of tumour. This is routinely done in every case of invasive breast carcinoma because patients with ER positive primary breast tumours are offered adjuvant hormone therapy, routinely tamoxifen for five years, while post menopausal women may receive aromatase inhibitor. Patients with overexpression of Her2 Neu are eligible for trastuzumab, a mAb that targets the Her2/Neu receptor. ${ }^{19,20}$

Breast carcinoma is the most common carcinoma in women and accounts for $22 \%$ of all female cancers which is more than twice the prevalence of cancer in women at any other site. In our study both male and female breast cancers were included and out of 82 cases only two were males. ${ }^{21}$ While in most of other studies either only female breast carcinomas were assessed or only male breast carcinomas.
In our study mostly patients were below 50 years of age which is quite similar to many local and international studies. ${ }^{8,22,23}$ Estrogen receptor is expressed in $70-80 \%$ of invasive ductal carcinoma, while PR is expressed in $60-70 \%$ of invasive breast carcinoma. ${ }^{8}$ In our study the ER was expressed in $56 \%$ of cases. While PR was expressed in $43.9 \%$ of cases and Her $2 / \mathrm{Neu}$ was expressed in $45.1 \%$ of cases. The expression of ER and PR is quite comparable to many international and local studies. The study conducted by Fatima et al., ${ }^{24}$ also showed ER positivity to be $52.4 \%$ very close to our study. Similarly a study conducted in India by Desai et al., ${ }^{25}$ showed ER positivity in 33\% of cases, $46 \%$ were PR positive. In their study ER and PR immune reactivity increased with advancing age. Ranatunga et al., ${ }^{26}$ observed ER and PR positivity in 53\% and 50\% of cases respectfully. Yip et al. ${ }^{27}$ reported that $50 \%$ of the cases were ER positive. Ong et al., ${ }^{22}$ reported $60 \%$ of the cases were ER positive. This may be because of the reason that most of the patients in our study were between $25-45$ years and in premenopausal age group where ER positivity is lower and it increases in post- menopausal age group and carcinomas were of high grade. In Nigerian woman, the most common reason for delayed presentation was fear of mastectomy with similar reasons identified by women from Pakistan. ${ }^{28}$ Considering the joint ER and PR positivity, in our study it was $30.4 \%$ while in the study by Desai et al., ${ }^{25}$ it was $25 \%$. In study by Ranatunga et al., ${ }^{26}$ it was $44 \%$. While in 
local studies like Sharif et al., ${ }^{8}$ the joint expression was $73.8 \%$ which is quite higher. ${ }^{28} \mathrm{~A}$ study conducted by Geethamala, ${ }^{29}$ it was $52 \%$ while by Bhagat et al., ${ }^{30}$ it was $36.2 \%$ and in a study by Suvarchala et al. ${ }^{23}$ it was $32.8 \%{ }^{31}$

The frequency of Her $2 / \mathrm{Neu}$ reactivity is $45.1 \%$ which is very much higher but is close to many international and local studies. In a study by Sharif et al., ${ }^{8}$ the Her $2 /$ Neu positivity was seen in $31 \%$ of cases. In a study conducted by Geethamala, ${ }^{29}$ it was $25 \% .{ }^{29}$ Lack of knowledge regarding necessity to visit, fear, negligence, lack of access to physicians and poverty are main reasons for delay In our study triple positive cases were $12 \%$ while in studies conducted by others, the number is none to one (Table 2). Our cases were all grade 3 because of Her2Neu positivity. In our study triple negative cases were almost $10 \%$ and were of all grade 3 , while study conducted by Suvarchala et al., ${ }^{23}$ its quite higher, $42.1 \%$ as compared to other studies (Table 2). They attributed this to differences in techniques of evaluation, higher tumour grades and majority being menopausal women. The two males included in this study were ER and PR receptors negative and were positive for Her2Neu over expression. In our study most tumours were of grade 2 which is again in concordance with many of the studies (Table 3). ${ }^{32}$ Considering the grade of tumour and hormonal receptors, mostly patients were of grade 2 and were hormonal receptors positive which is in concordance with study by Baswal et al. ${ }^{33}$ In our study there were no grade 1 tumours while in other studies (Table 4), there were cases of grade 1 and those were again hormonal receptors positive. While in the study by Biswal et al., ${ }^{33}$ there were also no grade 1 tumors. In our study grade 3 tumours were either triple negative, triple positive or Her2Neu positive which is again in concordance with other studies (Table 4). However we didn't have any case of grade 3 with hormone receptor positivity which is against other studies. ${ }^{23,31,32,34}$ However in one recent study which was carried out in India had more Grade 1 tumours and less grade 2 tumours as compared to our study. This explains that with advancing techniques to diagnose cancers at early stage can save patients lives. ${ }^{35}$

Table 3 Comparative incidence of frequency of grade of the tumor

\begin{tabular}{llllllll}
\hline $\begin{array}{l}\text { Grade of the } \\
\text { tumor }\end{array}$ & $\begin{array}{l}\text { Suvarchala et } \\
\text { al. } .^{23}\end{array}$ & $\begin{array}{l}\text { Bhagat et } \\
\text { al. } .^{30}\end{array}$ & $\begin{array}{l}\text { Shafaq et } \\
\text { al. } .^{31}\end{array}$ & $\begin{array}{l}\text { Javeria et } \\
\text { al. } .^{16}\end{array}$ & $\begin{array}{l}\text { Gethamala et } \\
\text { al. }{ }^{16}\end{array}$ & $\begin{array}{l}\text { Mushood et } \\
\text { al. } .^{22}\end{array}$ & $\begin{array}{l}\text { Present study } \\
\mathbf{2 0 1 6}\end{array}$ \\
\hline 1 & 28.12 & 27.58 & 18 & & 19 & 9.3 & - \\
2 & 42.18 & 43.1 & 45 & 53.9 & 54 & 46.7 & 69.5 \\
3 & 29.69 & 29.31 & 37 & 40.6 & 27 & 43.8 & 30.5 \\
\hline
\end{tabular}

Table 4 Comparison of hormone receptor status with grade of tumor

\begin{tabular}{|c|c|c|c|}
\hline \multirow{2}{*}{ Study } & \multicolumn{3}{|c|}{ Grade of tumor and Hormone receptor tumor } \\
\hline & Grade I & Grade 2 & Grade 3 \\
\hline \multirow{6}{*}{ Geethamala $^{16} \mathrm{~N}=100$} & $E R+/ P R+78.9 \%$ & $E R+/ P R+64.9 \%$ & $E R+/ P R+7.4 \%$ \\
\hline & $E R+/ P R-v e 5.3 \%$ & $\mathrm{ER}+/ \mathrm{PR}-\mathrm{vel} .8 \%$ & $E R+/ P R-v e 0 \%$ \\
\hline & $E R-/ P R+0 \%$ & $E R-/ P R+0 \%$ & $E R-/ P R+0 \%$ \\
\hline & ER-/PR-/Her2Neu $+15.8 \%$ & ER-/PR- / Her2Neu $+27.8 \%$ & ER-/PR- / Her2Neu $+26.4 \%$ \\
\hline & Triple negative $0 \%$ & Triple negative0\% & Triple negative62.9\% \\
\hline & Triple positive $0 \%$ & Triple positive $5.5 \%$ & Triple positive $3.3 \%$ \\
\hline \multirow{4}{*}{ Suvarchala et al. ${ }^{23} \mathrm{~N}=64$} & $E R+/ P R+33.3 \%$ & $E R+/ P R+5 I .85 \%$ & $E R+/ P R+5.26 \%$ \\
\hline & $\mathrm{ER}+/ \mathrm{PR}-\mathrm{ve} 5.5 \%$ & $E R+/ P R-v e 18.5 \%$ & $E R+/ P R-v e 15.7 \%$ \\
\hline & $E R-/ P R+5.5 \%$ & $E R-/ P R+7.41 \%$ & $E R-/ P R+21.05 \%$ \\
\hline & ER-/PR- $55.5 \%$ & ER-/PR- $22.2 \%$ & ER-/PR- $57.8 \%$ \\
\hline \multirow{4}{*}{ RituYadev et al. $.^{34} \mathrm{~N}=150$} & $E R+16.93 \%$ ER-ve $16.1 \%$ & $E R+24.62 \%$ ER-ve $26.9 \%$ & ER +0.7\% ER-ve $14.6 \%$ \\
\hline & $P R+15.38 \%$ PR-ve $17.7 \%$ & $P R+22.31 \%$ PR-ve $30.7 \%$ & $P R+1.54 \%$ PR-ve $12.31 \%$ \\
\hline & $\mathrm{Her} 2 \mathrm{Neu}+20.7 \%$ & Her $2 \mathrm{Neu}+27.7 \%$ Her2Neu-ve $20 \%$ & Her2Neu+9.24\% Her2Neu-ve $7.69 \%$ \\
\hline & Her2 Neu-ve $14.6 \%$ & & \\
\hline \multirow{4}{*}{ Mushood et al. ${ }^{32} \mathrm{~N}=139$} & $E R+/ P R+5.7 \%$ & $E R+/ P R+21.5 \%$ & $E R+/ P R+15.1 \%$ \\
\hline & $E R+/ P R-v e 0.7 \%$ & $E R+/ P R-v e 3.5 \%$ & $E R+/ P R-v e 2.8 \%$ \\
\hline & $E R-/ P R+0.7 \%$ & $E R-/ P R+2.1 \%$ & $E R-/ P R+4.3 \%$ \\
\hline & ER-/PR-/Her2Neu $+2.1 \%$ & ER-/PR- / Her2Neu $+19.4 \%$ & ER-/PR- / Her $2 \mathrm{Neu}+21.5 \%$ \\
\hline
\end{tabular}


Table continuded

\begin{tabular}{|c|c|c|c|}
\hline \multirow[t]{2}{*}{ Study } & \multicolumn{3}{|c|}{ Grade of tumor and Hormone receptor tumor } \\
\hline & - & $E R+/ P R+30.4 \%$ & $\mathrm{ER}+/ \mathrm{PR}+0 \%$ \\
\hline \multirow{5}{*}{ Present Study 2016 N= 82} & & $E R+/ P R-v e l 3 \%$ & $\mathrm{ER}+/ \mathrm{PR}-\mathrm{ve} 0 \%$ \\
\hline & & $E R-/ P R+1.2 \%$ & $E R-/ P R+0 \%$ \\
\hline & & ER-/PR- /Her $2 \mathrm{Neu}+13.4 \%$ & $\mathrm{ER}-/ \mathrm{PR}-/ \mathrm{Her} 2 \mathrm{Neu}+19.5 \%$ \\
\hline & & Triple negative $0 \%$ & Triple negative $9.7 \%$ \\
\hline & & Triple positive $10.9 \%$ & Triple positive $1.2 \%$ \\
\hline
\end{tabular}

\section{Conclusion}

Reactivity for steroid receptors was observed to be decreasing with increasing grade. Grade III tumor were more receptor status negative as compare to grade 1 and grade II tumor. This showed the same inverse relation between receptor status and increasing tumor grade.

\section{Acknowledgements}

None.

\section{Conflict of interest}

The author declares that there is none of the conflicts.

\section{References}

1. Yadav R, Sen $\mathrm{R}$, Preeti. Role of receptors in breast cancer. IJABR 2012;2(4):561-571.

2. Siddiqui MS, Kayani N, Sulaiman S, et al. Breast carcinoma in Pakistani females; a morphological study of 572 breast specimens. J Pak Med Assoc. 2000;50(6):174-177

3. Jemal A, Siegal R, Ward E, et al. Cancer statistics. CA cancer J Clin. 2007;57(1):43-66.

4. Borgen PI, Wong GY, VlamisV, et al. Current management of male breast cancer. A review of 104 cases. Ann Surg. 1992;215(5):451-457.

5. Fentiman IS, Fourquet A, Hortobagyi GN. Male breast cancer. Lancet 2006;367(9510):595-604.

6. Burstein HJ, Harris JR, Morrow M. Malignant tumors of the breast. In: De Vita VT, Lawrence TS, editors. Rosenberg SA: Cancer: Principles and Practice of Oncology. 9th ed. Philadelphia: Lippincott Williams \& Wilkins; 2011. p. 1401-1446.

7. Jatoi I, Miller AB. Why is breast cancer mortality declining? Lancet Oncol. 2003;4(4):251-254.

8. Sharif MA, Mamoon N, Mushtaq S, et al. Morphological profile and association of Her-2 Neu with prognostic markers in breast carcinoma in Northern Pakistan. J Coll Phy Surg Pak. 2009;19(2):99-103.

9. Rastelli F, Crispino S. Factors predictive response to hormone therapy in breast cancer. Tumouri. 2008;94(3):370-383.

10. Weigol MT, Dowsett M. Current and emerging biomarkers in breast cancer: prognosis and prediction. Endocr Relat cancer. 2010;17(4):245-262.

11. Ross JS, Fletcher JA. The Her2/neu oncogene in breast cancer: prognostic factor, predictive factor and target for therapy. Stem Cells. 1998;16(6):413428 .

12. Ross JS, Slodkowska EA, Symmans WF, et al. The Her-2 receptor and breast cancer: ten years of targeted anti Her2 therapy and personalized medicine. Oncologist. 2009;14(4):320-368.
13. Huang HJ, Neven P, Drijkoningen M, et al. Hormone receptors donot predict the Her2/neu status in all age groups of women with an operable breast cancer. Ann Oncol. 2005;16(11):1755-1761.

14. Clark GM. Prognostic and predictive factors. In: Harris JR, Lippman ME, Morrow M, editors. Diseases of the Breast. Philadelphia: LippincottRaven; 1996. p. 461-485.

15. Collins LC, Botero ML, Schnitt SJ. Bimodal frequency distribution of Estrogen Receptor immunohistochemical staining results in breast cancer. Am J Clin Pathol. 2005;123(1):16-20

16. Iqbal J, Abukhatir M, Shafi A, et al. Hormone receptor status of breast cancer in patients of different age groups, lymph node status histological type and tumor grade, an experience at King Fahad Medical City, Riyadh. Pak J Surg. 2014;30(4):296-300.

17. Gupta D, Gupta V, Marwah N, et al. Correlation of hormone receptor expression with histologic parameters in benign and malignant breast tumors. Iran J Pathol. 2015;10(1):23-34.

18. Payne SJ, Brown RL, Jones JL, et al. Predictive markers in breast cancerthe present. Histopathology. 2008;52(1):82-90.

19. Aitken SJ, Thomas JS, Langdon SP, et al. Quantitative analysis of changes in ER, PR and HER2 expression in primary breast cancer and paired nodal metastasis. Ann Oncol. 2010;21(6):1254-1261.

20. Gown AM. Current issues in ER and Her2 testing by IHC in breast cancer. Mod Pathol. 2008;21 Suppl 2:S8-S15.

21. Lal P, Tan LK, Chen B. Correlation of HER-2 status with estrogen and progesterone receptors and histologic features in 3,655 invasive breast carcinomas. Am J Clin Pathol. 2005;123(4):541-546.

22. Ong TA, Yip CH. Short term survival in breast cancer: The experience of the university of Malaya Medical centre. Asian J Surg. 2003;26(3):169175

23. Suvarchala SB, Nageswararao R. Carcinoma breast-histopathological and hormone receptors correlation. J Biosci Tech. 2011;2:340-348.

24. Fatima S, Faridi N, Gill S. Breast cancer. Steroid receptors and other prognostic indicators. J Coll Phy Surg Pak. 2004;15(4):230-233.

25. Desai SB, Moonim MT, Gill AK, et al. Hormone receptor status of braest cancer in India: A study of 798 tumours. Breast. 2000;9(5):267-270.

26. Ranatunga N, Liyanapathirana LV. Hormone receptor expression and Her2 /neu amplification in breast carcinoma in a cohort of Srilankans. Ceylon Med J. 2007;52(4):133-136.

27. Yip CH, Taib NA, Mohamed I. Epidemiology of breast cancer in Malaysia. Asian Pac J Cancer Prev. 2006;7(3):130-133.

28. Bhikoo R, Srinivasa S, Yu TC, et al. Systemic review of breast cancer biology in developing countries (part 2): Asian Subcontinental and South East Asia. Cancers (Basel). 2011;3(2):2382-2401. 
29. Geethamala K, Srinivasa Murthy V, BR Vani, et al. Histopathological Grade versus hormone receptor status in breast carcinoma treasure the past. International journal of biomedical research. 2015;6(7):466-471.

30. Bhagat Vasudha M, Jha Bharti M, Patel Prashant R. Correlation of hormonal receptor and her2 neu expression in breast cancer: A study at tertiary care hospital in south Gujarat. National Journal of medical research. 2012;2(3):295-298.

31. Mujtaba S, Haroon S, Faridi N, et al. Correlation of human epidermal growth factor receptor 2 (Her-2/neu) receptor status with hormone receptors Oestrogen receptor, progesterone receptor status and other prognostic markers in breast cancer: an experience at tertiary care hospital in Karachi. JPMA. 2013;63(7):854-858.

32. Nabi MG, Ahangar A, Kaneez S. Estrogen receptors, progesterone receptors and their correlation with respect to Her-2/neu status, histological grade, size of lesion, lymph node metastatsis, lymphovscular involvement and age in breast cancer patients in a hospital in north India. Asian Journal of Medical Sciences. 2016;7(3):28-34.
33. Baswal P, Behera S, Kar A, et al. Correlation of hormonal receptors estrogen receptor, progesterone receptor and Her2 Neu with tumor characteristics in breast carcinoma: Study of 100 consecutive cases. International Journal of Clinical Medicine. 2015;6:961-966.

34. Yadav R, Sen R, Chauhan P. ER, PR, Her2/Neu status and relation to clinicopathological factors in breast carcinoma. Int $J$ Pharm Pharm Sci. 2016;8(4):287-290.

35. Amit M, Parasad C, Sreeramulu P. Histopathological grade versus Estrogen and progesterone receptor status in carcinoma breast-A single centre study. Open Access J Surg. 2017;4(3):555-639. 